\title{
Preoperative Association of Abdominal Striae Gravidarum with Intraabdominal Adhesions in Pregnant Women with a History of Previous Cesarean Section: a Cross-sectional Study
}

\author{
Assoziation zwischen präoperative abdominelle Striae gravidarum und intraabdominellen Adhäsionen \\ in schwangeren Frauen, die mit Kaiserschnitt entbunden hatten
}

Authors

Affiliation
A. Dogan, I. E. Ertas, I. Uyar, I. Karaca, B. Bozgeyik, E. Töz, M. Ozeren

Department of Obstetrics and Gynecology, Tepecik Education and Research Hospital, Izmir, Turkey

\section{Key words \\ - pregnancy \\ - obstetrics \\ - cesarean \\ - adhesion \\ - striae gravidarum \\ Schlüsselwörter \\ - Schwangerschaft \\ - Geburtshilfe \\ - Kaiserschnitt \\ - Adhäsion \\ - Striae gravidarum}

\section{received 4.10.2015 revised 4.1.2016 accepted 23.1.2016}

\section{Bibliography}

DOI http://dx.doi.org/

10.1055/s-0042-101545

Geburtsh Frauenheilk 2016; 76:

268-272 @ Georg Thieme

Verlag KG Stuttgart · New York . ISSN 0016-5751

\section{Correspondence}

Dr. Askin Dogan

Tepecik Education and Research Hospital

Department of Obstetrics

and Gynecology

Gaziler Street number 468

Izmir 35170

Turkey

askindoganmd@gmail.com

\section{Abstract \\ $\nabla$}

Introduction: Intraabdominal adhesions that develop because of prior abdominal or pelvic surgery may cause problems during surgery. Complications can include difficult intraabdominal entry; injury to the urinary bladder, uterus or small intestine; longer operation times, and increased blood loss. The goal of the present study was to evaluate the association between abdominal striae gravidarum and intraabdominal adhesions in the preoperative period in pregnant women with a history of cesarean section.

Materials and Methods: The study included 247 pregnant women at $\geq 37$ weeks of gestation admitted to the labor unit for delivery; all had undergone at least one previous cesarean section. Abdominal striae were assessed preoperatively using the Davey scoring system; the severity and intensity of adhesions were subsequently evaluated intraoperatively according to the modified Nair scoring system.

Results: No striae were seen in 104 pregnant women; 41 had mild striae and 102 had severe striae. Overall, 113 cases had no adhesions (grade $0), 106$ had grade 1-2 adhesions, and 28 had grade 3-4 adhesions. Among patients with grade 0 adhesions, 34 (13.7\%) had no striae, while 79 (31.9\%) had mild-to-severe striae $(\mathrm{p}<0.001$; sensitivity $55 \%$; specificity $67 \%$; positive predictive value $69 \%$; negative predictive value $52 \%$ ). Among women with grade 1-2 adhesions, 48 (19.4\%) had no striae, while 58 (23.4\%) had mildto-severe striae. Finally, among women with grade 3-4 adhesions, 22 (8.9\%) had no striae, while $6(2.4 \%)$ had mild-to-severe striae $(\mathrm{p}<0.001)$. A p-value $<0.05$ was taken to indicate statistical significance.

Conclusions: The abdominal adhesion score dropped as the abdominal striae gravidarum score rose during the preoperative period. Addition of this useful, easy-to-apply, inexpensive, ad-

\section{Zusammenfassung \\ $\nabla$}

Einleitung: Intraabdominelle Adhäsionen, die durch frühere chirurgische Eingriffe am Bauch oder Becken entstehen, können zu Komplikationen bei späteren Eingriffen führen; zu den möglichen Komplikationen zählen Schwierigkeiten beim abdominellen Zugang; Verletzungen der Harnblase, der Gebärmutter oder des Dünndarms; längere Eingriffszeiten und höherer Blutverlust. Ziel dieser Studie war es, zu prüfen, ob es eine Assoziation gibt zwischen abdominellen Striae gravidarum und intraabdominellen Adhäsionen bei schwangeren Frauen, die mindestens einmal mit Kaiserschnitt entbunden haben.

Material und Methoden: Insgesamt 247 schwangere Frauen in der $\geq 37$. Schwangerschaftswoche, die zur Entbindung in die geburtshilfliche Station kamen, wurden in die Studie aufgenommen; alle schwangeren Frauen hatten vorher mindestens einmal schon per Kaiserschnitt entbunden. Abdominelle Geburtsstreifen wurden vor dem Kaiserschnitt mithilfe der Davey-Skala ausgewertet; der Schweregrad und die Intensität von intraabdominellen Adhäsionen wurden später intraoperativ mithilfe der modifizierten Nair-Skala bewertet. Ergebnisse: Bei 104 schwangeren Frauen fanden sich keine Geburtsstreifen; bei 41 Frauen fanden sich leichte Striae gravidarum, und 102 Frauen hatten stark ausgeprägte Geburtsstreifen. Insgesamt hatten 113 Frauen keine Adhäsionen (Grad 0), 106 Frauen hatten Adhäsionen 1.2. Grades und 28 Adhäsionen 3.-4.Grades. Von den Patientinnen mit Grad-0-Adhäsionen hatten 34 (13,7\%) Frauen keine Geburtsstreifen; 79 Frauen $(31,9 \%)$ hatten leicht bis stark ausgeprägte Geburtsstreifen ( $p<0,001$; Sensitivität, $55 \%$; Spezifität $67 \%$; positiver prädiktiver Wert $69 \%$; negativer prädiktiver Wert 52\%). In der Gruppe der Frauen mit Adhäsionen 1.-2. Grades hatten 48 (19,4\%) keine Geburtsstreifen und 58 (23,4\%) leicht bis stark ausgeprägte Geburtsstreifen. In 
junctive, observational, abdominal scoring method to the obstetrical work-up can provide important clues about the intraabdominal adhesion status of pregnant women scheduled for cesarean delivery because of previous cesarean section.

\section{Introduction}

$\nabla$

Intraabdominal adhesions caused by prior abdominal or pelvic surgery can cause morbidities such as intestinal obstruction, female infertility, and chronic pelvic pain postoperatively. In addition, adhesions may also cause problems during surgery; complications can include difficult intraabdominal entry; injury to the urinary bladder, uterus or small intestine; longer operation times, and increased blood loss [1-3]. Delivery by cesarean section is currently one of the most common obstetric operations, and the worldwide incidence of cesarean births has risen alarmingly [4]. Although the likelihood of intraabdominal adhesions is quite low in patients with no history of prior abdominal surgery or cesarean section, the probability of adhesion formation has been reported to be $7 \%$ after primary cesarean delivery, rising to $68 \%$ following a third cesarean delivery [5].

Estimating the likelihood of adhesions and related complications after prior surgery and assessing the severity of adhesion formation after surgery is not easy. Anticipating adhesions is very important to preventing complications by ensuring that the necessary preoperative preparations are in place and/or that appropriate cases are referred to a tertiary center.

Striae gravidarum (stretch marks) represent a skin change that can develop during pregnancy. It is characterized by thinning of the epidermis, loss of dermal papillae and rete ridges, and a decrease in the levels of collagen, fibronectin, and fibrils that form the extracellular matrix. Striae gravidarum are also present in some genetic diseases such as Marfan syndrome and Ehlers-Danlos syndrome [6].

The balance between fibrin deposition and degradation plays an important role in normal peritoneal healing and adhesion formation. Normal peritoneal healing can be described as complete fibrin degradation [7]. Fibroblasts play an active role in both peritoneal adhesions and striae formation as the cells synthesize collagen [8]. Incompletely degraded fibrin causes fibroblasts to produce collagen, and ineffective collagen degradation causes peritoneal adhesions. It is known that collagen plays a major role in striae development.

Thus, the development of striae gravidarum and adhesion formation are believed to share a common pathway and etiopathogenesis. A recent study with a small sample size showed that the presence of abdominal striae gravidarum could be used to predict intraperitoneal adhesion formation [9].

Given the above research, the goal of this study was to evaluate whether an association existed between abdominal striae gravidarum and intraabdominal adhesions in pregnant women sched- der Gruppe der Frauen mit Adhäsionen 3.-4. Grades hatten 22 $(8,9 \%)$ keine Striae gravidarum, und $6(2,4 \%)$ Frauen hatten leicht bis stark ausgeprägte Geburtsstreifen ( $<<0.001)$. Ein p-Wert von weniger als 0,05 wurde als statistisch signifikant gewertet.

Schlussfolgerung: Mit zunehmender Punktezahl für abdominelle Geburtsstreifen in der Zeit vor der Entbindung nahm die Punktezahl für abdominelle Adhäsionen ab. Die Verwendung dieses nützlichen, leicht anwendbaren, kostengünstigen, auf Beobachtung basierenden Scoringverfahrens als zusätzliche Untersuchung während der geburtshilflichen Abklärung bietet wichtige Hinweise zum Adhäsionsstatus schwangerer Frauen, bei denen aktuell ein Kaiserschnitt wegen früherer Entbindung per Sectio caesarea geplant ist.

uled for cesarean section because of a history of one or more prior cesarean sections.

\section{Material and Methods \\ $\nabla$}

Recruiting the study collective

In this cross-sectional prospective study, we evaluated 247 pregnant women at $\geq 37$ weeks of gestation, who were admitted to the labor unit of Tepecik Education and Research Hospital over a period of 4 months. All patients had a history of least one prior cesarean section and were therefore scheduled for further cesarean section. The study protocol was approved by the local ethics board of our institution.

\section{Inclusion and exclusion criteria}

Pregnant women who had conditions that might cause adhesion formation, such as pelvic inflammatory disease, prior abdominopelvic surgery other than cesarean section, or a history of endometriosis, were excluded. Pregnant woman who had developed wound site infections following prior cesarean section or who had a history of corticosteroid use that might cause striae formation were also excluded. Demographic data were recorded and included age, body mass index (BMI) on admission for delivery, weight gain during pregnancy, presence of gestational diabetes, smoking status, presence of chronic diseases (hepatitis, chronic anemia, chronic hypertension, bronchial asthma), number of previous cesarean sections and birth weight of the baby.

The study population was divided into groups according to the number of previous cesarean sections, and all women were evaluated preoperatively for striae using the Davey scoring system [10]. The abdomen was divided into four quadrants, using the midline and a line drawn horizontally through the umbilicus as references. Each quadrant was given a score, with 0 denoting clear skin, 1 a moderate (1-3) number of striae, and 2 many $(\geq 4)$ striae. The sum of the scores of all four quadrants was calculated to obtain the total striae score. Patients with no striae were classified into the "no striae" group. Patients with total striae scores of 1 or 2 were classified into the "mild striae" group, and patients with scores between 3 and 8 were classified into the "severe striae" group. We counted striae of all colors (reddish, glistening, and silvery lines) during abdominal skin examinations.

All previous cesarean operations were performed using the Pfannenstiel technique with parietal peritoneal closure. During surgery, intraabdominal peritoneal adhesions were evaluated according to the modified Nair scoring system [11]. Nair et al. described their classification system as follows: Grade 0: complete 
Table 1 Characteristics of patients with or without striae gravidarum according to Davey score.

\begin{tabular}{|c|c|c|c|c|}
\hline & No striae $(n=104)$ & Mild striae $(n=41)$ & Severe striae $(n=102)$ & p value \\
\hline Age $^{*}$ & $29.6 \pm 5.36$ & $29.5 \pm 5.85$ & $28.6 \pm 5.04$ & $0.342^{\mathrm{a}}$ \\
\hline BMI* & $28.6 \pm 4.09$ & $28.2 \pm 3.04$ & $30.6 \pm 4.3$ & $0.004^{b}$ \\
\hline Weight gain during pregnancy* & $9.78 \pm 3.83$ & $10.2 \pm 3.85$ & $11.4 \pm 5.1$ & $0.025^{b}$ \\
\hline Fetal birth weight* & $3036.1 \pm 615.5$ & $3142.5 \pm 574.9$ & $3308.4 \pm 570.1$ & $0.003^{b}$ \\
\hline Smoking** & & & & $0.559^{c}$ \\
\hline yes & $15(14.4)$ & $5(12.2)$ & $19(18.6)$ & \\
\hline no & $89(85.6)$ & $36(87.8)$ & $83(81.4)$ & \\
\hline History of chronic disease ${ }^{* *}$ & & & & $0.439^{c}$ \\
\hline yes & $10(10.1)$ & $8(17.3)$ & $17(16.6)$ & \\
\hline no & $89(89.9)$ & $38(82.7)$ & $85(83.4)$ & \\
\hline History of GDM** & & & & $0.253^{c}$ \\
\hline yes & $11(10.6)$ & $1(2.4)$ & $11(10.8)$ & \\
\hline$>$ no & $93(89.4)$ & $40(97.6)$ & $91(89.2)$ & \\
\hline
\end{tabular}

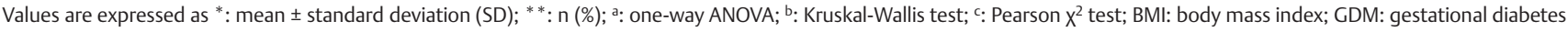
mellitus

absence of adhesions; Grade 1: single band of adhesion between viscera or from one viscera to the abdominal wall; Grade 2: two bands either between viscera or from viscera to the abdominal wall; Grade 3: more than two bands between viscera or from viscera to the abdominal wall, Grade 4: multiple dense adhesions or viscera directly adherent to the abdominal wall, irrespective of number or extent of adhesive bands. A modified Nair's scoring system was used to understand the relationship between abdominal striae and the adhesion scoring system. According to this modified classification system, adhesions were classified as grade 1 or 2 if filmy intraabdominal adhesions were present and as grade 3 or 4 if dense intraabdominal adhesions were present [12].

\section{Statistical analysis}

Continuous data and categorical data were expressed as mean \pm standard deviation and percentages (\%), respectively. The Shapiro-Wilk test was used to evaluate normal distribution. When comparing normally distributed groups, independent samples $\mathrm{t}$ test was used to compare two groups, and one-way analysis of variance (one-way ANOVA) was used to compare three or more groups. To compare non-normally distributed groups, MannWhitney U test was used when there were only two groups and Kruskal-Wallis $\mathrm{H}$ test was used when there were more than two groups. Analysis of cross tables was performed using the Pearson $\mathrm{X}^{2}$ test and the Continuity Correction $\mathrm{X}^{2}$ test. Analysis was performed using the IBM SPSS Statistics 21.0 program (IBM SPSS Statistics for Windows, version 21.0; Armonk, NY, USA). A p value of $<0.05$ was accepted as statistically significant.

\section{Results}

\section{Patient population}

The mean age at pregnancy was $29.4 \pm 5.2$ years and the mean gestational age was $37.8 \pm 1.8$ weeks. No striae were observed in 104 women, while 41 had mild and 102 severe striae. No adhesions were noted in 113 pregnant women (grade 0), while 106 had grade 1-2 adhesions and 28 had grade 3-4 adhesions.

\section{Patient characteristics}

When groups with and without striae were compared, no significant differences were found with regard to smoking status, the presence of chronic disease, or gestational diabetes; however, there were significant differences in BMI, weight gain during pregnancy, and fetal birth weight $(\mathrm{p}=0.04, \mathrm{p}=0.025$ and $p=0.03$, respectively). When patients were compared with regard to the presence of adhesions, no differences were found in terms of age, BMI, weight gain during pregnancy, fetal birth weight, cigarette smoking, or the presence of chronic disease and gestational diabetes; however, a statistically significant association was found between abdominal adhesions and the number of previous cesarean sections $(p=0.017)$. Demographic characteristics and the presence of striae and adhesions are listed in - Tables 1 and 2.

\section{Associations between striae and adhesion formation}

When the association between the presence of striae and adhesion formation was evaluated in pregnant women without adhesions, striae were detected in 79 women and were absent in 34 women $(p<0.001)$. The adhesion score decreased significantly when the striae score was high ( $p<0.001$ ), although the sensitivity and specificity were only moderate (sensitivity, $55 \%$; specificity, $67 \%$; positive predictive value, $69 \%$; negative predictive value, 52\%; O Table 3).

\section{Association between abdominal striae and adhesions according to Nair and Davey scoring systems}

No striae were found in 34 (13.7\%) pregnant women with grade 0 adhesions according to the modified Nair scoring system, while 79 women had mild-to-severe striae (31.9\%) according to the Davey scoring system $(\mathrm{p}<0.001)$. Among patients with grade $1-2$ adhesions, 48 (19.4\%) had no striae, while 58 (23.4\%) had mildto-severe striae. Among patients with grade 3-4 adhesions, 22 (8.9\%) had no striae, while 6 (2.4\%) had mild-to-severe striae ( $\mathrm{p}<0.001$; $\bullet$ Table 3$)$. 


\begin{tabular}{|c|c|c|c|c|}
\hline & Grade $0(n=113)$ & Grade $1-2(n=106)$ & Grade 3-4 $(n=28)$ & p value \\
\hline Age* $^{*}$ & $28.8 \pm 5.13$ & $29.3 \pm 5.34$ & $30.4 \pm 5.96$ & $0.367^{a}$ \\
\hline BMI* & $29.6 \pm 4.31$ & $29.1 \pm 4.06$ & $29.4 \pm 3.97$ & $0.67^{b}$ \\
\hline Weight gain during pregnancy* & $10.8 \pm 4.4$ & $10.3 \pm 4.5$ & $10.0 \pm 4.6$ & $0.755^{b}$ \\
\hline Fetal birth weight* & $3224.1 \pm 559.6$ & $3141.9 \pm 573.4$ & $3007.0 \pm 694.9$ & $0.30^{\mathrm{b}}$ \\
\hline \multicolumn{5}{|l|}{ Number of previous $\mathrm{CS}^{* *}$} \\
\hline > 1 & $57(50.4)$ & $54(50.9)$ & $14(50.0)$ & $0.017^{c}$ \\
\hline$>2$ & $54(47.8)$ & $42(39.6)$ & $11(39.3)$ & \\
\hline$>\geq 3$ & $2(1.8)$ & $10(9.4)$ & $3(10.7)$ & \\
\hline Smoking** & & & & $0.125^{c}$ \\
\hline yes & $22(19.5)$ & $11(10.4)$ & $6(21.4)$ & \\
\hline - no & $91(80.5)$ & $95(89.6)$ & $22(78.6)$ & \\
\hline History of chronic disease** & & & & $0.792^{c}$ \\
\hline - yes & $17(15.4)$ & $12(11.4)$ & $6(18.7)$ & \\
\hline no & $93(84.6)$ & $93(88.6)$ & $26(81.3)$ & \\
\hline History of GDM ${ }^{* *}$ & & & & $0.552^{c}$ \\
\hline - yes & $13(11.5)$ & $8(7.5)$ & $2(7.1)$ & \\
\hline no & $100(88.5)$ & $98(92.5)$ & $26(92.9)$ & \\
\hline
\end{tabular}

Values are expressed as *: mean \pm standard deviation (SD); **: n (\%); a: one-way ANOVA; ${ }^{\text {}: ~ K r u s k a l-W a l l i s ~ t e s t ; ~}{ }^{\circ}$ : Pearson $\mathrm{X}^{2}$ test; BMI: body mass index; CS: cesarean section; GDM: gestational diabetes mellitus. $\mathrm{p}<0.05$ was considered statistically significant

Table 3 Association between the presence of adhesions, adhesion grade, and striae gravidarum.

\begin{tabular}{|c|c|c|c|c|}
\hline & No striae $(n=104)$ & Mild striae $(n=41)$ & Severe striae $(n=102)$ & p value* \\
\hline Presence of adhesions & & & & $<0.001$ \\
\hline$\rightarrow$ yes & $70(67.3)$ & $27(65.9)$ & $37(36.3)$ & \\
\hline no & $34(32.7)$ & $14(34.1)$ & $65(63.7)$ & \\
\hline Adhesion grade & & & & $<0.001$ \\
\hline - Grade 0 & $34(32.7)$ & $14(34.1)$ & $65(63.7)$ & \\
\hline Grade 1-2 & $48(46.2)$ & $24(58.5)$ & $34(33.3)$ & \\
\hline - Grade 3-4 & $22(21.2)$ & $3(7.3)$ & $3(2.9)$ & \\
\hline
\end{tabular}

All values are expressed as $n(\%) .{ }^{*}$ : Pearson $x^{2}$ test

\section{Discussion}

$\nabla$

Prior cesarean section is an indication for further cesarean sections in $>90 \%$ of cases in the USA. It has been suggested that worldwide rates of cesarean delivery have increased alarmingly $[4,13]$. As the number of prior cesarean sections increases, the rate of complications also increases; adhesion formation is one of the most important causes of complications [14]. Adhesions make surgery more challenging (especially the presence of dense adhesions). Reported complications include injury to the intestine and urinary bladder, higher blood loss and hematoma formation [15]. Although intraperitoneal adhesions may develop following any intraabdominal surgical intervention and may increase following repeated abdominal surgery such as cesarean section, adhesion formation is a variable and highly unpredictable process.

Therefore, we aimed to answer the question whether an association existed between abdominal striae gravidarum and intraperitoneal adhesion formation in pregnant women scheduled for cesarean delivery because of prior cesarean section.

Mits et al. showed that dysfunctional fibroblasts, which are metabolically effective in healthy tissues in the absence of striae, were present in individuals with striae [6]. Dysfunctional fibroblasts cannot respond appropriately to mechanical stretching. In addition, the extracellular matrix is not capable of rapid self-regeneration. Mits et al. also indicated that this condition may be genetic in origin. Gungor et al. showed that striae gravidarum is a genetic condition but reported no association with collagen gene polymorphisms [16].

The biology of adhesion formation within the peritoneal cavity is not clearly understood. In the literature, adhesion tissue is described as a consequence of peritoneal injury, ischemia, increased vascular permeability, and exudation of inflammatory cells, with subsequent production of a fibrin matrix. Although the fibrin matrix is an approximation of an injured peritoneal surface, the matrix is subsequently replaced by fibroblasts, macrophages and giant cells. Fibrin bands are removed fibrinolytically and healthy tissue develops. Any condition that disrupts fibrinolytic activity results in adhesion formation. Adhesion tissue is formed by macrophages, eosinophils, erythrocytes, tissue debris, mast cells, and fibroblasts [17].

In a recent study that included a small number of patients $(n=55)$, Gungor et al. reported more adhesion formation in pregnant women with more pronounced striae gravidarum [9]. However, in our study of 247 pregnant women, both adhesion formation and the intensity of adhesions were reduced in the presence of abdominal striae.

It has been demonstrated histopathologically that adhesion tissue contains collagen fibrils produced by fibroblasts that are located in the extracellular matrix. It is also known that defective fibroblasts play a role in striae formation and produce less collagen [6]. Although there is no general consensus on an association 
between striae and adhesion formation, we suggest that the reduced adhesion formation seen in pregnant women with striae gravidarum is due to impaired fibroblast activity that plays roles in both striae production and adhesion formation. These defective fibroblasts deposit less collagen in adhesion tissue during formation of the extracellular matrix. Therefore, fibrinolytic activity is less effective in such patients and adhesion formation occurs.

In the present study, although adhesion scores significantly decreased when the striae scores were higher $(\mathrm{p}<0.001)$, the sensitivity and specificity were only moderate (sensitivity, $55 \%$; specificity, 67\%; positive predictive value, 69\%; negative predictive value, $52 \%$ ). We suggest that the preoperative evaluation of abdominal striae gravidarum can provide surgeons with information on the abdominal adhesion status in the preoperative period. As expected and previously showed by others [1,3], our study found a statistically significant association between abdominal adhesions and the number of previous cesarean sections. Kapadia et al. reported on the effect of connective tissue collagen on skin elasticity [18]. They found that perineal lacerations were more common during vaginal delivery in patients with striae gravidarum secondary to defective collagen synthesis.

One strength of the present prospective cross-sectional study, which evaluated the association between abdominal striae gravidarum and intraabdominal adhesion status, was the relatively large sample size.

The limitations of the present study were as follows: we analyzed the associations between striae gravidarum and intraabdominal adhesions only in the abdominal area, excluding any striae on the breasts or thighs; the color of the striae was not taken into consideration; and the study population lacked ethnic diversity.

\section{Conclusions for Practice}

During the preoperative period, the addition of our useful, easyto-apply, inexpensive, adjunctive, observational, abdominal scoring method to the obstetrical work-up can provide important clues on the intraabdominal adhesion status of pregnant women scheduled for cesarean delivery because of previous cesarean section. Moreover, in this population - especially in pregnant women with no abdominal striae - surgical dissection should be meticulous and particular care should be paid during abdominal entry to avoid complications that can lead to maternal morbidity and mortality.

\section{Conflict of Interest}

None.

\section{References}

1 Diamond MP, Freeman ML. Clinical implications of postsurgical adhesions. Hum Reprod Update 2001; 7: 567-576

2 Ten Broek RP, Schreinemacher MH, Jilesen AP et al. Enterotomy risk in abdominal wall repair: a prospective study. Ann Surg 2012; 256: 280287

3 Ten Broek RP, Strik C, Issa Y et al. Adhesiolysis-related morbidity in abdominal surgery. Ann Surg 2013; 258: 98-106

4 Simsek Y, Celen S, Ertas E et al. Alarming rise of cesarean births: a single center experience. Eur Rev Med Pharmacol Sci 2012; 16: 1102-1106

5 Rossouw JN, Hall D, Harvey J. Time between skin incision and delivery during cesarean. Int J Gynaecol Obstet 2013; 121: 82-85

6 Mitts TF, Jimenez F, Hinek A. Skin biopsy analysis reveals predisposition to stretch mark formation. Aesthet Surg J 2005; 25: 593-600

7 Arung $W$, Meurisse M, Detry O. Pathophysiology and prevention of postoperative peritoneal adhesions. World J Gastroenterol 2011; 17: 4545-4553

$8 \mathrm{Xu}$ X, Rivkind A, Pappo O et al. Role of mast cells and myofibroblasts in human peritoneal adhesion formation. Ann Surg 2002; 236: 593-601

9 Cakir Gungor AN, Oguz S, Hacivelioglu S et al. Predictive value of striae gravidarum severity for intraperitoneal adhesions or uterine scar healing in patients with previous caesarean delivery. J Matern Fetal Neonatal Med 2014; 27: 1312-1315

10 Davey CM. Factors associated with the occurrence of striae gravidarum. J Obstet Gynaecol Br Commonw 1972; 79: 1113-1114

11 Kahyaoglu I, Kayikcioglu F, Kinay T et al. Abdominal scar characteristics: do they predict intra-abdominal adhesions with repeat cesarean deliveries? J Obstet Gynaecol Res 2014; 40: 1643-1648

12 Nair SK, Bhat IK, Aurora AR. Role of proteolytic enzyme in the prevention of postoperative intraperitoneal adhesions. Arch Surg 1974; 108 : 849-853

13 Martin JA, Hamilton BE, Ventura SJ et al. Births: final data for 2009. Natl Vital Stat Rep 2011; 60: 1-70

14 Silver RM, Landon MB, Rouse DJ et al. Maternal morbidity associated with multiple repeat cesarean deliveries. Obstet Gynecol 2006; 107: 1226-1232

15 Nisenblat V, Barak S, Griness OB et al. Maternal complications associated with multiple cesarean deliveries. Obstet Gynecol 2006; 108: 2126

16 Cakir Gungor AN, Oguz S, Uludag A et al. Striae gravidarum is genetic but not releated with collagen gene polymorphism. Gene Ther Mol Biol 2014; 15: 131-137

17 Cheong YC, Laird SM, Li TC et al. Peritoneal healing and adhesion formation/reformation. Hum Reprod Update 2001; 7: 556-566

18 Kapadia S, Kapoor S, Parmar K et al. Prediction of perineal tear during childbirth by assessment of striae gravidarum score. Int J Reprod Contracept Obstet Gynecol 2014; 3: 208-212 